\title{
Verski in romarski turizem
}

Tadeja Jere Jakulin

UP Fakulteta za turistične študije - Turistica

tadeja.jerejakulin@fts.upr.si

Poglavje obravnava temeljne pojme, motive in značilnosti romanj kot verskega gibanja, odkriva vzporedne povezave in razlike med romarskim ter verskim turizmom, predstavlja razlike med romarjem, verskim in kulturnim turistom. Ob tem se dotakne še predstavitve priljubljenih svetovnih in evropskih romarskih središč ter štirih marijanskih svetišč na področju držav na območju Alp in Jadrana, ki so povzročila razcvet romarskega turizma in verskih prireditev v Sloveniji, Italiji, Avstriji ter na Hrvaškem. Verovanja in z njimi povezana romanja so v zgodovini svetovnih religij močno vplivala na oblikovanje kultur, kot jih poznamo danes. Število romarjev, različnih vrst romanj, romarskih poti in romarskih mest se iz leta v leto povečuje. Povečuje pa se tudi turistična ponudba, ki spremlja verske turiste in romarje na njihovih poteh. Kot pišeta Griffin in Raj (2017), svetišča in verski kraji za turizem predstavljajo najrazličnejše ponudbe, od storitev, glasbe in drugih strukturiranih dejavnosti verske narave do posvetnejših objektov za obiskovalce, kot so muzeji in zakladnice, ki se nahajajo znotraj njihovih čudovitih zgodovinskih zgradb. Po drugi strani pa ne le romarski temveč verski turizem predstavlja mehko

Lesjak, M., Sikošek, M., in Kerma, S. (ur.). (2020). Tematski turizem: teoretični in aplikativni primeri oblik turizma $v$ svetu in Sloveniji. 
moč nacionalne in mednarodne ekonomije (Bhonsale, 2019). Na številnih mestih obiskovalce spodbujajo, naj spoštujejo svetost mesta da se ustavijo za razmislek, prižgejo sveče in se vključijo v duhovno prakso, hkrati pa jih spodbudijo, da se povzpnejo na zvonik in očarani pogledajo estetiko arhitekture. Temu opisu ustrezajo tudi opisana svetišča. Lepota narave, arhitekture, hkrati pa odločnost romarjev, ki sledijo svoji poti, dajejo turizmu okus žlahtne globine, ki presega misel o površnem turistu s fotoaparatom in se nasloni na podobo turista - romarja, ki se ustavlja in vedno znova vrača v okolje miru in novega upanja.

\section{Pojem, motivi in značilnosti romanja}

Po Federovi (2016) v svetu obstaja na tisoče romarskih mest, ki jih vsakoletno obiskujejo številni privrženci različnih veroizpovedi. Romarska mesta in poti pa so hkrati tudi del srednjeveške dediščine Evrope (Lidén, 2019). Poleg velikega števila obstoječih romarskih središč pa obstaja tudi večje število definicij za romanje. Romanje lahko definiramo kot "potovanje posameznika ali skupine vernikov na določen kraj ali k določenemu svetišču, njegov motiv pa je obet božje pomoči« (Petrič, 2008), lahko ga opredelimo tudi kot fizično potovanje, ki pogosto odraža življenjsko pot vsakega posameznika v iskanju resnice oz. nečesa svetega (Devereux in Carnegie, 2006; Olsen in Timothy, 2006). Motivi za romanje so različni, nikakor le verski, kljub temu, da je glavni motiv verovanje. Motiv za romanja skozi zgodovino je bilo upanje na dobro fizično in mentalno zdravje (Lidén, 2019). Ljudje, ki romajo dandanašnji, niso nujno stalni obiskovalci cerkve (Nolan in Nolan, 1992). V Evropi je število redno prisotnih vernikov v cerkvi močno upadlo, število romarskih obiskov v zadnjem stoletju pa se je povečalo. Na romarsko pot se lahko odpravi posameznik sam ali v skupini. Romanje je povezano s turizmom preko nastanitev in prehrane, ki spremljajo romarja na njegovi poti.

\section{Razvoj romanj}

V krščanstvu so se romanja začela razvijati zelo zgodaj. Obstajajo viri, ki govorijo o tem, da naj bi se neke vrste romanj razvile že v zelo oddaljenih časih. Sprva so verniki obiskovali kraje Kristusovega trpljenja in grobove zgodnjih mučencev, ker so verjeli, da imajo relikvije posebno moč. Zelo hitro so se oblikovala tri najpomembnejša romarska središča, Rim, Santiago de Compostela in Jeruzalem, v 
srednjem veku pa je bilo med slovenskim prebivalstvom priljubljeno tudi romanje v Kelmorajn ( $\mathrm{k}$ relikvijam Köln, Aachen in Trier), kamor so romali na vsakih sedem let (Kemperl, 2016).

Antična ljudstva so romala v templje in svetišča $\mathrm{z}$ namenom opravljanja verskih obredov. Najbolj znano takšno romanje je potekalo od Aten do Elevsine. Svetišča so se načeloma nahajala v mirnih predelih s čistim zrakom in z zeleno naravo. V zgodnjem starem veku so romarji potovali predvsem na krajše razdalje, dandanes pa postajajo vse atraktivnejša daljša romarska potovanja (Šorn, 2009). V starem veku so ljudje potovali predvsem zaradi iskanja ugodnejših razmer od tistih, ki so jih imeli doma. V tistem obdobju ni bilo gostišč, ki bi ljudem nudila zavetje in hrano. Potovanja po stari Grčiji so bila osredotočena predvsem na verske in zdravstvene motive in so vključevala obisk verskih središč (med najpomembnejšimi romarsko središče Delfi) ter zdraviliških krajev (npr. Evbeja, Epidavrus). Občasno so ljudje "potovali« tudi na ogled športnih prireditev (najprepoznavnejše so olimpijske igre, Olimpija). Tudi potovanja starih Rimljanov so potekala iz enakih razlogov, verskih in zdravstvenih. Edino prevozno sredstvo tedanjega časa so bile kočije s konjsko vprego (»Zgodovinski razvoj turizma«, 2018).

V srednjem veku so se organizacije romanj odvijale v 11. stoletju, in sicer s strani križarjev, ki so s svojimi ladjami po morju romarje popeljali v Jeruzalem, Betlehem in Nazaret (Šorn, 2009). Izmed vseh oblik potovanj srednjeveškega prebivalstva so romanja zajela najširši spekter družbe. Romali so vsi, od najnižjega do najvišjega sloja; romalo je plemstvo, bogato meščanstvo, obrtniki, kmetje, služabniki in hlapci. Osnovni motiv je bil seveda verski, a je bilo čutiti tudi pridih drugih dejavnikov - želja po potovanju, po spoznavanju novih destinacij, beg pred tegobami doma in podobni motivi (Kosi, 1997). Krščanske romarje so v preteklosti nastanjali v samostane, kasneje, ob ustanavljanju »hospicov«, pa so slednji prevzeli funkcijo njihove nastanitve. Delovali so kot gostišča s prenočiščem, pogosto poimenovani tudi "gostoljubna hiša«. Do poznega srednjega veka so bila prenočišča v hospicih brezplačna. Le-ti so bili med seboj v večini oddaljeni za en dan hoje (Šorn, 2009). V 16. stoletju je romanja prekinila reformacija, katere cilj je bila preureditev rimskokatoliške Cerkve. Pri nas je bil največji zagovornik tega gibanja Primož Trubar, ki je bil tudi velik nasprotnik romanj (Kemperl, 2016).

Marijanske poti (božje poti, ki poveličujejo Marijo) so se razmno- 
žile predvsem v obdobju protireformacije in baroka, med 16. in 18. stoletjem. V tem času so se dodobra razvila tudi romarska središča Altötting, Mariazell, Trsat, Guadalupe, Einsideln, Lurd, Santiago in mnoga druga (Šorn, 2009). Po obdobju reformacije, ki je bila romarjem zelo nenaklonjena, so protireformatorski škofje ob pomoči redov oživili stara in zgradili nova romarska središča. Protireformacijo je podprl tudi Ferdinand, ki je kasneje postal cesar (Ferdinand II.), in na podlagi uveljavitve njegovega odloka iz leta 1626 so morali vsi nekatoliški plemiči zapustiti njegove dedne dežele (Kemperl, 2016). $\mathrm{V}$ času baroka romanje ni imelo več le religiozni, temveč tudi ekonomski dejavnik. Vsaka župnija je poleg individualnih romanj organizirala od deset do petnajst romarskih procesij, ki so se odvijale v času od maja do septembra.

V 17. stoletju so romanja doživela nov razmah, uredili in postavili so veliko romarskih cerkev in nikoli poprej kot tudi nikoli kasneje romanja niso bila tako množična kot v tistem obdobju, med letoma 1630 in 1770 (Kemperl, 2016). Najverodostojnejši viri, ki pričajo o romanju v 17. in 18. stoletju, so župnijske "matrikule« oziroma opravilniki. "Matrikula je neke vrste liturgični koledar, kamor so župniki zapisovali, katere naloge so na določen dan v letu v župniji morali opraviti, torej tudi vse romarske procese.« (Kemperl, 2016, str. 143) Dober, a nekoliko manj verodostojen vir, ki priča o romanju v novem veku, so tudi župnijske in samostanske kronike, knjige oziroma popisi čudežev in bratovščinske vpisne knjige.

Za obravnavani čas 17. in 18. stoletja se je ohranilo izjemno malo kronik, jih je pa bilo dosti napisanih v 19. stoletju, ko so o čudodelnih ozdravljenjih pisali za nazaj. Ti popisi so dober vir za preučevanje bolezni tistega časa ter za analizo motivov za romanje na določen kraj (Kemperl, 2016). Čas vladanja Jožefa II. je bil romarjem najmanj naklonjen, saj je le-ta z dvornim dekretom leta 1783 odredil ukinitev vseh procesij in bratovščin, leto dni kasneje pa zaprtje vseh romarskih cerkva. To so reševali tako, da so slednje na hitro spreminjali v župnijske cerkve (Kemperl, 2016).

$\mathrm{V}$ 19. in 20. stoletju se je romarski turizem močno moderniziral. K temu je botroval razvoj prometne infrastrukture in prevoznih sredstev. »Z razvojem industrializacije in železniškega prometa v 19. stoletju so se pospešila tudi romanja." (Šorn, 2009, str. 70) Ob povečanju števila romarjev se je seveda višal tudi ekonomski interes in na veliko se je začela graditi nova infrastruktura (namestitveni objekti, 
gostilne itn.). Razvoju turizma se je moralo prilagoditi tudi lokalno prebivalstvo.

V obdobju med obema vojnama se romarski turizem ni ustavil. Zaradi boljše prometne povezave in pridobljene železnice je na našem območju zaživelo Brezje, kamor je romalo med 150.000 in 200.000 romarjev letno (Šorn, 2009). Erberhart (2004) omenja, da narodopisje že 25 do 30 (danes vsaj 40) let opaža močno naraščanje romanj, »ki je v prvih desetletjih po vojni deloma izgubljalo svoj pomen« (str. 35). Iz starih pisnih virov vemo, da so bili najpogostejši vzroki, ki so naše prednike vodili na romanje v svete kraje, bolezen, nesreča, osebna prizadetost $\mathrm{v}$ vojni in roparski napadi.

V zadnjih letih te motive deloma izpodrivajo novi, sodobnejši: družina, partnerstvo, medsebojni odnosi, šola, svetovni mir in mnogi drugi, ki odražajo vsakdanja življenjska vprašanja. Sveti kraji so čedalje bolj v ospredju, saj ljudje potrebujejo in ves čas iščejo stabilnost, ki pa jo lahko najdejo ravno v spiritualnosti in ritualu (Erberhart, 2004). Po drugi strani pa je mnogo sodobnih romanj povezanih s premagovanjem samih sebe, fizičnim trpljenjem in z mentalno odločenostjo, da romar doseže določeno stopnjo svetosti, ko doseže cilj svojega romanja (Marques idr., 2019). Če razloge za višanje števila romarjev v zadnjem času iščemo dalje, lahko izpostavimo turizem. Ta je že zdavnaj spoznal, »da romanje tudi v katoliški Evropi ni več izključno aktivnost katoliških kristjanov, ampak se dogaja v skupnem družbenem procesu« (Erberhart, 2004, str. 47).

\section{Verski, romarski in klasični turizem}

$\mathrm{Z}$ romanjem povezan verskega turizma je bil tisti, kjer romar išče nenavadne izkušnje skozi ves čas romanja (Kim idr., 2019). S preučevanjem iskanja povezav in razlik med turizmom in vero se v največji meri ukvarjajo teologi. Ti zavračajo možnost označevanj potovanj $\mathrm{z}$ verskim ozadjem $\mathrm{s}$ "turističnimi potovanji«, ker osnovni motiv za potovanje ni turističen, temveč religiozen. Seveda pa drži dejstvo, da morajo verniki na svojem popotovanju tudi jesti, piti in prenočiti, vendar to ni zadosten argument, da potovanje dobi oznako "turistično« (Šorn, 2009). Stausberg (2010) navaja nasprotja, ki povezujejo turizem in religijo. Za turizem pravi, da ga označujejo zabavnost, rekreacija, prosti čas in tostranstvo, medtem ko so značilnosti vere svetost, globina, iskrenost, odrešitev, dolžnost in onostranstvo. $\mathrm{V}$ prepletu turizma in vere se jasno pokaže, da turist na potovanju 
proti svetemu mestu išče mnogo več kot le zabavo. Odpravlja se na romanje, vzroki zanj pa niso površni. Vzroki, zaradi katerih se ljudje odločajo za obisk romarskih središč, so lahko posledica (Šorn, 2009):

1. klasičnega turizma (zadovoljevanje potrebe po zabavi, počitku ipd.),

2. verskega turizma (zadovoljevanje notranje potrebe po duševnem miru, ki ga dosežejo z obiskom procesij in maš),

3. klasičnoverskega turizma (mešanica klasičnega turizma z verskim; ljudje v času svojega klasičnega potovanja obiščejo tudi sakralne objekte, lahko tudi verske obrede, vendar primaren cilj potovanja ni verski motiv).

Prepletanja verskega in klasičnega turizma ter verskega in duhovnega turizma so čedalje tesnejša. Verski turizem je povezan s kulturo in kulturno dediščino starih imperijev, ki so bili poleg vojaških osvajanj tudi imperiji potovanj (MacKenzie, 2005). Potovanja so bila igrišča za bogate, ki so raziskovali različne oblike kulturne dediščine. Poleg lokacij za širjenje krščanstva, ki naj bi jih oblikoval božji in evangeličanski namen, so potovanja ponudila najboljše dokaze o napredku, ki je definiral meščansko filozofijo neke dobe (MacKenzie, 2005). Versko potovanje, ki se zaradi narave potovanje spremeni v verski turizem, lahko označimo kot: potovanje do verske destinacije, potovanje $\mathrm{z}$ misijonarsko ali s humanitarno namero, potovanje $\mathrm{k}$ verskemu shodu, potovanje z namenom druženja ali prostega časa.

Verski turizem se najpogosteje pojavlja v eni izmed treh oblik turizma: kot romanje skupine ali individualnega obiska verskih svetišč, kot množična zbirališča ob pomembnih verskih obletnicah in kot obiski krajev ter objektov bogatega verskega pomena v okviru turističnega potovanja (Vukonić, 1990). Poimenovanje potovanja vključuje: romanja, konvencije, srečanja in prireditve, križarjenja, pustolovska potovanja, prostovoljne počitnice, odhode na vikende, umik, obiske znamenitosti, prosti čas. Terminologija, ki se pojavlja pri verskih potovanjih, se navezuje na verska in duhovna potovanja, verski turizem, verska potovanja in gostoljubnost, popotovanja, ki temeljijo na veri.

Preglednica 2.1 prikazuje razlikovanje romarskega in verskega turizma, kot ga je opisal Fahey (2002). Predstavlja centralni element obeh aktivnosti ter razlike, ki izhajajo iz motivacije romarja ali romarskega turista. Element verovanja vedno vsebuje pobožnost ro- 
Preglednica 2.1 Razlike med romarskim in verskim turizmom

\begin{tabular}{lll}
\hline Element & Verski/romarski turizem & Klasični turizem \\
\hline Vera & Pobožnost & Ni zahtevana \\
\hline Pokora & Iskanje celovitosti & Ni zahtevana \\
\hline Skupina & $\begin{array}{l}\text { Pogosto samotno, a bi morala } \\
\text { biti odprta za vse }\end{array}$ & $\begin{array}{l}\text { Pogosto s prijatelji in z } \\
\text { družino ali izbrano interesno } \\
\text { skupino }\end{array}$ \\
\hline Sveti prostor & Tišina za ustvarjanje & Ni prisoten \\
& notranjega svetega prostora & \\
\hline Obred & $\begin{array}{l}\text { Eksternalizira spremembo } \\
\text { znotraj }\end{array}$ & Ni prisoten \\
\hline Votivno darovanje & $\begin{array}{l}\text { Človek za seboj pusti del sebe, } \\
\text { se prepusti iskanju boljšega }\end{array}$ & $\begin{array}{l}\text { Ni prisotno; potovanje je } \\
\text { dobro življenje }\end{array}$ \\
& življenja & \\
\hline Praznovanje & »Zmaga nad seboj«, & Popivanje z namenom pozabe \\
& praznovanje za spomin & \\
Vztrajnost & $\begin{array}{l}\text { Zavezanost; »romanja ni } \\
\text { nikoli konec« }\end{array}$ & Počitnic bo kmalu konec \\
\hline
\end{tabular}

Opombe Prirejeno po Fahey (2002).

marja, medtem ko pri romarskem turistu vera ni zahtevana. Isto velja za pokoro. Romanje je praviloma samotno, romar ustvarja sveti prostor s tem, ko se odmakne od gneče v samoto, išče smisel in boljše življenje, pozunanji notranjo spremembo in se zaveda, da romanje nikoli ni zadnje, da se vedno nadaljuje. $Z$ razliko od turističnega romarja ali turista $v$ romarskih središčih, ki večinoma potuje tja $\mathrm{z}$ družino ali prijatelji, v njegovi zavesti svetost prostora, votivnega darovanja in obredja niso bistvena, najbolj pa se razlikuje pri elementih praznovanja in vztrajnosti, saj turist zadnja dva elementa dojema kot fizično akcijo (popivanje) in razmišljanje, da bo počitnic kmalu konec, medtem ko romar praznuje zmago nad seboj in se vedno znova zaveda, da njegovo potovanje ni končano, da se njegovo iskanje (romanje) nadaljuje. Verski turizem se osredotoča na obisk verskih krajev s ciljem, da se poveže s oz. poglobi v svojo notranjo vero (Federova, 2016).

Verski turizem ima v gospodarskem smislu dosti pozitivnih učinkov: prispevanje k ohranjanju dediščine versko pomembnih krajev, krepitev ekonomije. Približno dvajset odstotkov območij na seznamu UnEsco-ve svetovne dediščine ima versko ali duhovno povezavo (unesco, b.l.). Status svetovne dediščine lahko turističnim de- 
stinacijam prinese konkurenčno prednost. Okoli sebe lahko gradijo svojo podobo kot verskoturistična destinacija. Učinek masovnega turizem negativno vpliva na raven religioznosti vseh, ki v turističnih krajih živijo (Cohen, 1998, str. 7). Slabi lokalno spoštovanje do veroizpovedi in prepričanja $\mathrm{v}$ »svetost « svetih krajev, obredov ali običajev. Tipičen primer v svetu je vsem poznana gora Sinai, kjer so se menihi iz samostana sv. Katarine začeli pritoževati, da planina izgublja pridih nedotakljivosti in svetega, ker tam vsako noč kampira med 300 do 500 ljudi. Menihi verjamejo, da ta dejavnost in onesnaževanje $z$ odpadki in hrup, ki prideta $\mathrm{z}$ njo, močno vplivata na svetost gore in $\mathrm{s}$ tem uničujeta njeno dušo. Množična romanja s seboj prinesejo negativne vidike tudi pri organizaciji potovanj, saj se nemalokrat pojavijo določene težave glede organizacije prihoda in odhoda, prehrane, prenočitvenih zmogljivosti in zdravstvene zaščite (Šorn, 2009). Romarska središča se dandanes tržijo preko potovalnih agencij, natisnjeni so številni potovalni vodiči po zgodovinskih romarskih poteh pa tudi splošni romarski vodiči. Turistične organizacije pospešeno odpirajo nove tržne produkte destinacij, uvajajo lastne tematske poti, ki med seboj povezujejo cerkve, verska spominska mesta in energijske kraje. Značilnost verskega turizma so obredi, ki se lahko spremenijo v večdnevne prireditve in praznovanja ali pa trajajo le kratek čas. Pri razvoju razumevanja vplivov, ki oblikujejo verske obrede in njihov pomen, R. Dowson (2019) navaja nekaj dejavnikov, ki vplivajo na trende verskih in duhovnih potovanj. Ti dejavniki, med drugim, vključujejo prostor, čas in kulturni kontekst dogodkov, kjer se zaključuje sveto popotovanje.

\section{Priljubljena svetovna in evropska verska središča, objekti čaščenja in romarske poti}

Vsako leto na milijone ljudi potuje na romarska mesta; nekateri kot romarji, drugi kot turisti in tretji kot verski turisti v skupinah. Motivi za verska potovanja ali romanja so različni glede na segmentacijo popotnikov. Romarji iščejo višji smisel in za njih je pot pomembnejša kot sam cilj. Turisti ali verski turisti pa so osredotočeni predvsem na cilj in zunanje doživljanje romarskega središča.

Preglednica 2.2 predstavlja deset najbolj priljubljenih svetovnih verskih središč oziroma objektov čaščenja in romanj (Top 1o Most Popular Pilgrimage Sites Around the World, 2018). Jeruzalem privablja obiskovalce iz vse države in po vsem svetu zaradi svoje edinstvene 
Preglednica 2.2 Deset najbolj priljubljenih svetovnih verskih središč

\begin{tabular}{|c|c|c|c|c|}
\hline (1) & (2) & (3) & (4) & (5) \\
\hline Jeruzalem & Izrael & $\begin{array}{l}\text { Staro mestno } \\
\text { jedro }\end{array}$ & Rimskokatoliška & 1.792 .900 \\
\hline Meka & Saudska Arabija & Hajj, romanje & Islam & 2.489 .406 \\
\hline Vatikan & Vatikan & $\begin{array}{l}\text { Bazilika Svetega } \\
\text { Petra, Sikstin- } \\
\text { ska kapela }\end{array}$ & Rimskokatoliška & 3.952 .140 \\
\hline Betlehem & Palestina & $\begin{array}{l}\text { Božične prire- } \\
\text { ditve }\end{array}$ & $\begin{array}{l}\text { Rimsko katoli- } \\
\text { ška }\end{array}$ & 2.000 .000 \\
\hline Šri Pada & Šri Lanka & $\begin{array}{l}\text { Gora Adamov } \\
\text { vrh }\end{array}$ & $\begin{array}{l}\text { Theravada bu- } \\
\text { disti, hindujci, } \\
\text { muslimani in } \\
\text { kristjani. }\end{array}$ & 2.000 .000 \\
\hline Reka Ganges & Indija & Ritual čiščenja & Hinduizem & 20.000 .000 \\
\hline Altötting & Nemčija & Črna Madona & Rimskokatoliška & 1.000 .000 \\
\hline Jeruzalem & Izrael & $\begin{array}{l}\text { Zahodni zid, ri- } \\
\text { tual objokova- } \\
\text { nja in daritve }\end{array}$ & Rimskokatoliška & 1.595681 \\
\hline Gora Arafat & Savdska Arabija & $\begin{array}{l}\text { Dan kesanja in } \\
\text { sprejemanja } \\
\text { prošenj }\end{array}$ & Islam & 2.000 .000 \\
\hline Bodhi Gaya & Indija & $\begin{array}{l}\text { Drevo duhovne } \\
\text { osvoboditve - } \\
\text { mitsko svetov- } \\
\text { no drevo }\end{array}$ & Budizem & $\begin{array}{l}800.000- \\
1.000 .000\end{array}$ \\
\hline
\end{tabular}

Opombe Naslovi stolpcev: (1) romarsko središče, (2) država, (3) mesto romanja, verska prireditev ali objekt čaščenja, (4) religija, (5) letno število romarjev. Prirejeno po Top 10 Most Popular Pilgrimage Sites Around the World (2018).

kulturne in verske dediščine za tri monoteistične religije ter zgodovinskih, arheoloških najdišč in kulturnih središč, ki jih lahko ponudi. V zadnjih treh letih se je število gostov v Izraelu na splošno in posebej v Jeruzalemu postopno povečevalo, v letu 2018 jih je bilo 1.792.90o (Korach in Choshen, 2019). Romanje v Meko, imenovano Hajj, je v lanskem letu zabeležilo 2.489.406 muslimanskih romarjev (General Authority for Statistics, Kingdom of Saudi Arabia, 2019). Hajj predstavlja večdnevno izvajanje zaporedja obredov, vse v namen pokore Bogu. Vatikan je postal neodvisna država leta 1929.

Hkrati je sveto mesto za katoličane in tudi sveti prostor številnih spomenikov ter zgradb, kot so bazilika svetega Petra, Sikstinska kapela, vatikanski vrtovi in številni čudoviti muzeji (An Increasing 
Number of Pilgrims, 2018). Romarji prihajajo v Betlehem vse leto, pri čemer je nizka sezona $v$ zimskih mesecih od novembra do februarja. Vendar je božič vrhunec. Vsako leto več kot dva milijona turistov in romarjev obišče Jezusovo rojstno hišo (Bethlehem Municipality b. 1.).

Šri Pada ali Adamov vrh na Šri Lanki je gora, ki je posvečena štirim glavnim religijam na svetu. Letno približno 20.000 romarjev, ki so najrazličnejših starosti, telesne pripravljenosti in verskih prepričanj, prevzame nalogo plezanja na Adamov vrh v iskanju moralnega in duhovnega pomena. Reko Ganges, ki teče skozi Indijo in Bangladeš, obišče skoraj 20 milijonov vernikov letno. Za tiste, ki živijo okoli rečnega območja, reka predstavlja življenje, čistost in tudi boginjo.

Altötting je bavarsko romarsko središče, ki časti devico Marijo. Vsako leto se več kot milijon romarjev poda v kapelo milosti in časti njeno Črno Madono.

Zahodni zid v Jeruzalemu, znan tudi kot zid objokovanja, je edini del strukture, ki je ostal od drugega Salomonovega templja. Po mnenju Judov zid predstavlja Božjo navzočnost in privablja milijone ljudi $\mathrm{z}$ vsega sveta. Tam ljudje molijo in na papirnate lističe pišejo molitve, ki jih namestijo v razpoke znotraj stene. Dan Arafe je pomemben dan islamskega romanja v Meko. Na ta dan se na ravnicah gore Arafat zbere sto tisoč ljudi; to je namreč dan kesanja in sprejemanja prošenj. V letu 2019 se je na ta dan zbralo več kot 2 milijona muslimanov (Yeranian, 2019).

Bodh Gaya v Biharju ali drevo razsvetljenja se nahaja v Indiji, ki je podcelina hinduizma, sikhizma, budizma in džainizma, in je eno najbolj priljubljenih romarskih mest. To drevo naj bi bilo tam, kjer je Siddharta Gautama, znan tudi kot Buda, dosegel razsvetljenje po 49dnevni meditaciji. Vsako leto ga obišče približno 800.000 do milijon ljudi, ki prihajajo predvsem iz Azije.

Tudi v evropskem okolju je veliko priljubljenih romarskih središč, ki so locirana v mesnih katedralah, podeželskih cerkvah in do katerih vodijo različne romarske poti. Deset priljubljenih romarskih poti in središče predstavlja spodnji seznam.

Preglednica 2.3 osvetljuje nekatera priljubljena romarska središča in mesta na evropski celini. Uradniki v marijanskem svetišču v Fatimi pravijo, da je leta 2019630 milijonov romarjev obiskalo znamenito mesto na osrednjem Portugalskem Santiago de Compostela, ki z istoimensko katedralo pomeni zadnjo točki romarske poti sv. Jakoba (Rudolf, 2004). Poti je več in so različno dolge. Ena najstarejših ro- 
Preglednica 2.3 Deset najbolj priljubljenih evropskih verskih središč

\begin{tabular}{|c|c|c|c|c|}
\hline (1) & (2) & (3) & (4) & (5) \\
\hline Fatima & Portugalska & $\begin{array}{l}\text { Staro mestno } \\
\text { jedro }\end{array}$ & Rimskokatoliška & 6.300 .000 \\
\hline $\begin{array}{l}\text { Santiago de } \\
\text { Compostela }\end{array}$ & Španija & $\begin{array}{l}\text { Jakobova ro- } \\
\text { marska pot }\end{array}$ & Rimskokatoliška & 347.538 \\
\hline Lurd & Francija & $\begin{array}{l}\text { Lurdsko sveti- } \\
\text { šče }\end{array}$ & Rimskokatoliška & 1.300 .00 \\
\hline Armagh & Irska & $\begin{array}{l}\text { Patrikova ro- } \\
\text { marska pot, } \\
\text { Cerkev sv. Patri- } \\
\text { ka }\end{array}$ & $\begin{array}{l}\text { Protestantska } \\
\text { in katoliška }\end{array}$ & 422.000 \\
\hline Einsiedeln, & Švica & Črna Madona & Kalvinistična & $\begin{array}{r}150.000- \\
200.000\end{array}$ \\
\hline Altötting & Nemčija & Črna Madona & Rimskokatoliška & 1.000 .000 \\
\hline $\begin{array}{l}\text { Luthrova } \\
\text { dežela }\end{array}$ & Nemčija & $\begin{array}{l}\text { Mesto Witten- } \\
\text { berg, Luthrove } \\
\text { poti }\end{array}$ & Protestantska & 117.220 \\
\hline Czenstohova & Poljska & Črna Madona & Rimskokatoliška & 4.000 .000 \\
\hline Međugorje & $\begin{array}{l}\text { Bosna in } \\
\text { Hercegovina }\end{array}$ & $\begin{array}{l}\text { Marijino prika- } \\
\text { zovanje }\end{array}$ & Rimskokatoliška & 2.500 .000 \\
\hline Assissi & Italija & $\begin{array}{l}\text { Bazilika San } \\
\text { Francesco, } \\
\text { Frančiškova pot }\end{array}$ & Rimskokatoliška & 6.000 .000 \\
\hline
\end{tabular}

Opombe Naslovi stolpcev: (1) romarsko središče, (2) država, (3) mesto romanja, verska prireditev ali objekt čaščenja, (4) religija, (5) letno število romarjev. Prirejeno po po 20 Top Pilgrimage Sites in Europe (b. l.).

marskih poti na svetu poteka skozi severno Španijo, konča pa se pri katedrali Santiago de Compostela.

V Franciji je največje romarsko mesto Lurd, ki sprejme približno pet milijonov romarjev na leto. Lurd dobiva pomen s prikazovanjem Gospe Lurdske in je mesto številnih čudežnih ozdravitev. Obiskovalci in romarji obiskujejo lurdsko svetišče, običajno imenovano Domena. Ta vključuje Grotto, kjer romarji lahko na 126 hektarjih pijejo lurdsko vodo iz pipe in ima 22 ločenih krajev čaščenja.

Na severnem Irskem je mesto Armagh, ki ima korenine v keltskem poganstvu. Ko se je krščanstvo v 400 letih prejšnjega stoletja razširilo na to regijo, je sveti Patrik tam ustanovil svojo cerkev in Armagh je postal cerkvena prestolnica otoka. Odločil je, da so za širjenje evangelija sposobni samo tisti, ki se izobražujejo v Armaghu, zato so 
bile ustanovljene številne izobraževalne ustanove. Armagh (Lawlor, 2008) je sedež protestantskih in katoliških nadškofov. Zanimivi sta rimokatoliška katedrala sv. Patrika in anglikanska katedrala sv. Patrika ter romarska pot Sv. Patrika.

V Švici je mestece Einsiedeln, ki spada v nemški del Jakobove poti (romanja v Santiago de Compostela) in ki je postalo popularen kot verska turistična destinacija zahvaljujoč benediktinski opatiji. Več kot 100.000 verskih turistov letno obišče kip Črne Madone v opatiji razkošno okrašene baročne cerkve (On the Way of St. James in Switzerland, b. 1.).

Nemški Altötting je tudi na evropski listi in je našel svoj priljubljenost med romarji. Poleg Altöttinga je nemški turizem namenil pozornost organizaciji Lutrove dežele (Eichel, 2015), kjer je deloval verski reformator Martin Luther. Ker statistični podatki za celotno področje niso dostopni, je številka 117.220 obiskovalcev, ki jo prestavlja preglednica, veljavna za mesto Wittenberg, kjer se je Martin Luther rodil, večino svojega življenja živel in kjer je leta 1517 na vrata pribil svojih 95 tez ali zahtev po reformi.

Svetišče, posvečeno Črni Madoni, v Čenstohovi na Poljskem, na leto privabi več kot štiri milijone obiskovalcev in simbolizira odločenost Poljakov, da ohranjajo svojo dediščino. Slika Črne Madone je doživela čudeže. 800 let stare zgradbe okoli samostana se preživljajo s turistično trgovino.

Medžugorje, svetišče v Bosni in Hercegovini, je od vseh najmlajše. Marijina prikazovanja so se od leta 1981 v Medžugorju pojavila pred šestimi otroki (Klimek, 2019) in je mesto postalo priljubljena romarska destinacija. Spletna stran vsako leto privabi milijon ljudi, od katerih so bili nekateri priča nebesom, vključno s srci in križi okoli sonca. Italijansko mesto Assisi, je najbolj znano po tem, da je bil to rojstni kraj svetega Frančiška. Na njegov vpliv se spominja v baziliki San Francesco iz Assisija, ki je bila poimenovana kot svetovna dediščina. "Frančiškov učinek« na mesto se zdi resničen: od prvega papeževega obiska leta 2013 se je število obiskovalcev Assisija povečalo s 4,5 milijona na 6 milijonov na leto (McKenna, 2016).

Na območju Alp in Jadrana, križišču slovansko-germansko-italijanskih kultur, so najbolj obiskana štiri romarska središča včasih pripadala ozemlju Slovenije. Zanimivo je dejstvo, da so vsa štiri svetišča marijanska (tj. posvečena sveti materi božji oziroma devici Mariji).

Preglednica 2.4 prikazuje Brezje, Trsat, Marijino Celje in Sv. Višarje, ki so marijanska svetišča in centri romarskih poti držav na območju 
Preglednica 2.4 Nekdanja slovenska, danes evropska Marijanska romarska svetišča

\begin{tabular}{llllr}
\hline$(1)$ & $(2)$ & $(3)$ & $(4)$ & $(5)$ \\
\hline Brezje & Slovenija & $\begin{array}{l}\text { Bazilika Marije } \\
\text { Pomagaj }\end{array}$ & Rimskokatoliška & 400.000 \\
\hline Trsat & Hrvaška & $\begin{array}{l}\text { Bazilika svete de- } \\
\text { vice Marije }\end{array}$ & Rimskokatoliška & 140.000 \\
\hline $\begin{array}{l}\text { Maria Zell (slovensko } \\
\text { ime Marijino Celje) }\end{array}$ & Avstrija & $\begin{array}{l}\text { Bazilika Marijine- } \\
\text { ga rojstva }\end{array}$ & Rimskokatoliška & 700.000 \\
\hline $\begin{array}{l}\text { Monte Lussari (sloven- } \\
\text { sko ime Sv. Višarje) }\end{array}$ & Italija & $\begin{array}{l}\text { Cerkev Svete Ma- } \\
\text { rije na Višavah }\end{array}$ & Rimskokatoliška & 100.000 \\
\hline
\end{tabular}

Opombe Naslovi stolpcev: (1) romarsko središče, (2) država, (3) mesto romanja, verska prireditev ali objekt čaščenja, (4) religija, (5) letno število romarjev.

Alp in Jadrana: Slovenije, Hrvaške, Avstrije in Italije. Posebna so zato, ker so še v prejšnjem stoletju pripadala Sloveniji, danes pa slovenske romarje v veliki meri dopolnjujejo evropski. Brezje letno obišče prek 400.000 obiskovalcev, največ romarjev pa se vsako leto zbere ob prazniku Marijinega vnebovzetja, 15. avgusta. Na predvečer praznika na Brezjah poteka slovesno bogoslužje s procesijo (Slovesnosti pri Mariji Pomagaj, b.1.). Najpomembnejši verski dogodek na Trsatu je zagotovo praznik velikega šmarna (bolj poznan kot Marijino vnebovzetje), ko je Trsat zaprt za promet in mesto napolnijo romarji iz vseh krajev. Takrat potekajo tudi tradicionalni sejem in številne druge prireditve (Ivelja-Dalmatin idr., 2009).

Marijino Celje spada v graško nadškofijo, vsako leto pa ga obišče milijon romarjev. Obisk iz dežel nekdanjega vzhodnega bloka naj bi se po padcu berlinskega zidu povečal. Petrič (2008) ta kraj še danes označuje za priljubljeno božjepotno svetišče. Svete Višarje veljajo za eno izmed najstarejših, najvišje ležečih ( $1789 \mathrm{~m}$ ) in najbolj priljubljenih božjih poti med slovenskimi romarji. Zanje pravijo, da so in tja še vedno romajo Slovenci iz tako rekoč »treh Slovenij«, pri čemer se nanašajo na Slovence iz domovine, zamejstva in izseljenstva. Petrič (2008) omenja čudeže, ki naj bi se v 18. stoletju dogajali na Svetih Višarjih, ter podaja informacijo, da je tisti čas, ko so za to izvedeli, tja odromalo po 100.000 romarjev s Koroške, Kranjske, Štajerske, Goriške in iz Furlanije.

\section{Zaključek}

V krščanstvu so se romanja začela razvijati zelo zgodaj. Romanje je imelo v preteklosti velik pomen za romarje, ki so poleg verskega mo- 
tiva za pot spoznavali nove kraje, drugačno kulturo in načine življenja. Na ta način se je začela razvijati nova oblika turizma, ki jo lahko primerjamo z obliko današnjega sodobnega turizma (Foster, 1986). Današnje romarske kraje in svetišča obiskujejo tako romarji kot klasični turisti, ki so ali pa niso nujno religiozni. Ko ljudje potujejo in obiskujejo verske kraje kot turisti, je zanje pomemben cilj in obisk svetišča ali pa, da dobijo potrditve o svoji veri. Za romarja pa je pomembna pot, stik s samim seboj, da lahko razmišlja in išče smisel. Oboji pa bi se želeli osebno povezati s svetim krajem, bolje razumeti in ceniti vero, se počutiti brez skrbi, najti mir in smisel v življenju (What Are the Opportunities for Religious Tourism from Europe? b.1.).

Najbolj znane in najbolj obiskane destinacije verskega turizma so tiste, ki so omenjene v večjih verskih knjigah, kot sta Jeruzalem (Sveto pismo) in Meka (Koran). Druge verske destinacije morda niso tako stare, vendar so kljub vsemu izjemno znane in priljubljene, na primer Fatima, Santiago de Compostela, Lurd, Medžugorje in ostale destinacije. Evropski verski turisti strogo versko doživetje radi kombinirajo s kulturnimi ali prostovoljnimi dejavnostmi. Hkrati pa romarski in verski turizem postajata gospodarska generatorja na vseh območjih, ki jih romarji in turisti obiskujejo. Verski turizem ima namreč široko ponudbo za popotnika: verske turistične atrakcije, prireditve, obiske samostanov in muzeje, storitve, ki so bile razvite za zadovoljevanje njihovih potreb, ter namestitve, ki niso nujno turistične (hoteli, penzioni, turistične sobe), lahko so tudi samostanske, to so tista prenočišča, ki pripadajo cerkvam in župnijam in ki romarju omogočajo umik ter kontemplacijo v prostem času ali v času verskih srečanj in shodov.

\section{Literatura}

20 top pilgrimage sites in Europe. (B. 1.). Religious Travel Planning Guide. https://religioustravelplanningguide.com/20-top-pilgrimage -sites-in-europe/

An increasing number of pilgrims made visits to the Vatican in 2017. (2018, 1. februar). News: Information and Analysis of the Life of the Church. https://fsspx.news/en/news-events/news/increasing -number-pilgrims-made-visits-vatican-2017-35394

Bethlehem Municipality. (B. 1.). The city economy. http://www.bethlehem -city.org/en/index-16.php?Mid=NDg\%3D

Bhonsale, M. (2019). Religious tourism as soft power: Strengthening In- 
dia's outreach to Southeast Asia (ORF Special Report No. 97). Observer Research Foundation.

Cohen, E. (1998). Tourism and religion. Pacific Tourism Review, 2(1), 1-10. Devereux, C., in Carnegie, E. 2006. Pilgrimage: Journeying beyond self. Journal of Tourism Recreation Research, 31(1), 47-56.

Dowson, R. (2019). The role of rituals and sacred joureys. V R. Dowson, J. Yakub in R. Raj (ur.), Spiritual and religious tourism: Motivations and management (str. 9-20). САВ I.

Eichel, C. (2015). Deutschland, Lutherland: Warum uns die Reformation bis heute prägt. Karl Blessing Verlag.

On the way of St. James in Switzerland: Constance-Rapperswil-Einsiedeln 'Swabian way.' (B. 1.). [Brošura]. https://www.jakobsweg.ch/assets/ Dokumente-Jakobsweg/Wegleitungen-E/ASchwabenwegE.pdf

Eberhart, H. (2004). Romanje: sodobne težnje in raziskovalni prijemi. Traditiones, 33(1), 35-56.

Fahey, F. (2002). Pilgrims or tourists? The Furrow, 53(4), 213-218.

Fedorova, A. (2016). New product development in spiritual tourism [neobjavljeno diplomsko delo]. University of Eastern Finland.

Foster, N. (1986). Hodočasnici. GZH.

General Authority for Statistics, Kingdom of Saudi Arabia. (2019). Hajj statistics 2019-1440 [brošura]. https://www.stats.gov.sa/sites/default /files/haj_40_en.pdf

Griffin, K., in Raj, R. (2017). The importance of religious tourism and pilgrimage: Reflecting on definitions, motives and data. International Journal of Religious Tourism and Pilgrimage, 5(3), članek 2. https://doi.org/10.21427/D7242Z

Ivelja-Dalmatin, A., Njavro, M., Perišin, M., Vranješ, I., in Vranješ, M. (2009). Marijin Trsat. Frančiškanski samostan na Trsatu.

Kemperl, M. (2016). Značilnosti romanj v 17. in 18. stoletju na Slovenskem. Edinost in dialog, 71, 141-152.

Kim, B., Kim, S., in King, B. (2019). Religious tourism studies: Evolution, progress, and future prospects. Tourism Recreation Research, 45(4), $1-19$.

Klimek, D. M. (2019) Medjugorje and the supernatural: Science, mysticism, and extraordinary religious experience. Oxford University Press.

Korach, M., in Choshen, M. (2019). Jerusalem: Facts and trends 2019. Jerusalem Institute for Policy Research.

Kosi, M. (1997). Potujoči srednji vek. Kronika, 45(1/2), 8-26.

Lawlor, H. J. (2008). St Bernard of Clairvaux's life of St Malachy of Armagh. MacMillan.

Lidén, A. (2019). Pilgrim tourists motivation in religious heritage, culture and art. V R. Dowson, J. Yakub in R. Raj (ur.), Spiritual and religious tourism: Motivations and management (str. 73-85). CABI. 
MacKenzie, J. M. (2005). Empires of travel: British guide books and cultural imperialism in the 19th and 2oth centuries. V J. Walton (ur.), Histories of tourism: Representation, identity and conflict (str. 18-39). Channel View.

Marques, L. M., Silva, V. de P. da, in Santos, J. C. V. (2019). The pilgrim goes to the festival: Changes in daily life caused by the pilgrimage to the shrine of Our Lady of the Abadia in Romaria, Brazil. V R. Dowson, J. Yakub in R. Raj (ur.), Spiritual and religious tourism: Motivations and management (str. 135-143). САВ .

McKenna, J. (2016, 18. september). A pope named Francis proves boon for Assisi tourism. Crux. https://cruxnow.com/global-church/2016/og/ pope-named-francis-proves-boon-assisi-tourism/

Nolan, M. L., and Nolan, S. (1992). Religious sites as tourism attractions in Europe. Annals of Tourism Research, 19(1), 68-78.

Olsen, D. H., in Timothy, D. (2006). Tourism and religious journeys. V. D. Timothy in D. H. Olsen (ur.), Tourism, religion and spiritual journeys (str. 1-21). Routledge.

Petrič, F. (2008). Slovenske božje poti. Ljubljana: Družina.

Rudolf, C. (2004). Culture trails and adventures in travel: Pilgrimage to the end of the world - The road to Santiago de Compostela. University of Chicago Press.

Slovesnosti pri Mariji Pomagaj. (B.1.). Slovensko Marijino narodno svetišče. http://www.marija.si/dozivite-brezje/slovesnosti-pri-marijipomagaj/

Stausberg, M. (2010). Religion im modernen Tourismus. Verlag der Weltreligionen.

Šorn, M. (2009). Romanje in romarska središča $v$ Evropi [neobjavljeno diplomsko delo]. Univerza v Ljubljani.

Top 10 most popular pilgrimage sites around the world. (2018, 24 marec). All Time Lists. https://alltimelists.com/10-popular-pilgrimagesites-world/

UNESCO. (B. 1.). Heritage of religious interest. https://whc.unesco.org/en /religious-sacred-heritage/

Vukonić, B. (1990). Turizam i religija. Acta turistica, 2(2), 209-212.

What are the opportunities for religious tourism from Europe? (B.1.). СВ I. https://www.cbi.eu/market-information/tourism/religious -tourism-o

Yeranian, E. (2019, 10. avgust). More than 2 million muslim pilgrims reach Hajj High Point. Voa News. https:/ / www.voanews.com/middleeast/more-2-million-muslim-pilgrims-reach-hajj-high-point 